Comunicação e Sociedade, vol. 19, 2011, pp.

\title{
Publicidade ou o ser-corpo da filosofia
}

Helena Pires

\begin{abstract}
Enfin, du point de vue du politique, la publicité représente une tentative parodique, donc ultime, de sauver le sens et la représentation comme seuls modes possibles pour concevoir l'idée d'une collectivité en acte. Même si c'est sur le mode altéré de la société de consommation de soi, la publicité propose la dernière version de la représentation, cette fiction nécessaire au commerce symbolique entre les humains afin qu'il y ait du collectif.
\end{abstract}

(Quessada, 2002: 186)

As práticas, os usos, os discursos e as representações compõem algumas das dimensões de discussão e análise do fenómeno publicitário, tão diversas quanto complexas. $\mathrm{O}$ presente número da revista Comunicação e Sociedade procura, precisamente, conceder espaço à pluralidade de abordagens e à inevitável multidisciplinaridade que uma tal área de estudos exige. Tratando-se de uma especialidade académica ainda relativamente jovem em Portugal, tanto ao nível do ensino como ao nível da investigação, a publicidade tem-se prestado porém, sobretudo mais recentemente, a frequentes estudos de natureza múltipla: ora pautados pela preocupação com a eficácia comunicativa, e como tal particularmente interessados em contribuir para o desenvolvimento das práticas profissionais da actividade, ora pautados pelo objectivo da simples compreensão das experiências e dos usos, em termos de percepção e de interacção por parte dos cidadãos e consumidores ou, ainda, estudos pautados pela análise da mensagem publicitária, desdobrando-se esta última perspectiva, quer sobre o registo formal, quer sobre o registo semântico-referencial, o que inclui, entre outras, a abordagem linguística, mas também a análise do discurso.

Em particular, os textos que aqui se publicam, ao mesmo tempo que ilustram uma tal variedade, poderão entender-se como indicativos da tendência para o recorte de algumas temáticas ou abordagens, em detrimento de outras, o que por sua vez nos poderá oferecer uma oportunidade para indagar, na actualidade, sobre o correr dos tempos. Em primeiro lugar, denota-se que a importância atribuída aos média, na convicção de que por 
si mesmos estes implicam diferentes linguagens, diferentes técnicas e estratégias de comunicação, continua a justificar, por meio de um tom de emergente novidade, uma parte significativa dos estudos em publicidade. O aparecimento dos designados novos média tem mobilizado, desde então, alguns investigadores que procuram apreender novas potencialidades e/ou novas ameaças. Assim é com «Formatos da publicidade digital: sistematização e desambiguação» (Sónia Sebastião), com "A convergência da revista Atrevida nas redes sociais: novas práticas publicitárias nos meios de comunicação" (Letícia Salem Herrmann Lima), com «Blogs: portas abertas para as marcas na cibercultura» (Larissa Almada), ou ainda com «Estratégias da comunicação online dirigidas às crianças portuguesas» (Francisco Costa Pereira, Jorge Veríssimo e Maria do Rosário Correia). Admitindo-se a «ecrãnização global» (Lipovetsky e Serroy, 2007) da experiência e da cultura contemporâneas, pensar sobre os seus efeitos na publicidade, de um ponto de vista mais ou menos instrumental, impõe-se, na verdade, como um imperativo incontornável. Do mesmo modo, e em segundo lugar, são as novas oportunidades estratégicas, em geral, impulsionadas por transformações sociais e culturais, ao nível das práticas e das representações, que inspiram o estudo de novos entendimentos sobre a própria comunicação estratégica, bem como sobre a natureza e objecto da actividade dita publicitária: «Ecobranding. A Revolution in the new media age» (Herlander Dias), "Comunicação low-cost: desinvestimento ou fórmula de sucesso?» (Carla Pereira, António Azevedo e Teresa Ruão), «Publicidade? Aqui não, obrigado’: auto-retrato com paisagem em fundo e vista para a cidade» (Ana Melo), "Outdoor personalizado: base de dados online e perspectivas de análise» (Francisco Mesquita), «O despertar da publicidade cidadã» (Sara Balonas), «Publicitar o Ensino Superior: modernidade ou inconveniência?» (Teresa Ruão). Em terceiro lugar, salientamos as pesquisas e/ou reflexões que visam esclarecer sobre casos particulares ou mesmo sobre a realidade portuguesa, na perspectiva dos comportamentos, da imagem construída ou das percepções: «O papel da publicidade na compra de produtos cosméticos» (Francisco Costa Pereira, Ana Cristina Antunes e Sofia Nobre), «Publicidade institucional e marca organizacional: caso EDP Renováveis» (Renata Suely de Freitas e Teresa Ruão), "A utilização de tabus enquanto estratégia publicitária: uma análise do seu impacto e grau de aceitação em consumidores portugueses» (Elsa Simões e Paulo Cardoso), «O simbolismo das marcas no discurso publicitário contemporâneo. O capital simbólico da Yorn» (Cristina Santos). Por fim, e em quarto lugar, destacam-se os artigos que, ora abordam o discurso publicitário - «Para além da superfície visual: os anúncios publicitários vistos à luz da semiótica social. Representações e discursos da heterossexualidade e de género» (Silvana Mota-Ribeiro e Zara Pinto-Coelho), «Discourse and manipulation - the miscegenation of genres in written press» (Alexandra Guedes Pinto), «Sobre o papel das estratégias linguísticas nas mensagens publicitárias em outdoors: uma análise de cartazes produzidos por alunos de Ciências da Comunicação» (Elsa Simões Lucas Freitas e Sandra Tuna) -, ora investem numa reflexão crítica sobre o carácter fundamental do próprio conceito de publicidade - «The Public as social experience» (Samuel Mateus) -, ou ainda traduzem, de modo especial, a perspectiva sociológica - «A publicidade na pesquisa sociológica em Portugal: vazio ou domínio emergente?» (Alcina Dourado), «O ritual da comunicação e o ritual do consumo: novas tribos, novos rituais» (Susana Silva). 
Discutindo-se hoje o papel da publicidade no quadro de uma sociedade vivamente afectada pela saturação visual, pela impregnação das diversas paisagens mediáticas de todo o tipo de estímulos e apelos, dirigidos a indivíduos por sua vez permanentemente apetrechados de múltiplos dispositivos tecnológicos que convidam ao desdobramento das acções, dos sentidos, das identidades, das experiências, torna-se imperioso pensar sobre o modo como os anunciantes, os criativos, os consumidores, bem como os cidadãos em geral reinventam as suas práticas ou respondem, simplesmente, neste contexto. Fará sentido discutir actualmente o fim da publicidade, no seguimento do persistente debate sobre a extinção da polis, do espaço público, pelo menos no sentido territorial, entendido como espaço de partilha e do exercício da razão crítica? Em última análise, fará sentido discutir o fim da própria filosofia? Não será a publicidade, tal como defende Dominique Quessada (2002), uma espécie de herdeira última da prática argumentativa, emprestando expressão visível à vida-com-os-outros no seio do espaço público e cultura urbana? Uma espécie de ser-corpo da filosofia e da cultura?

A natureza da publicidade em si mesma poderá também ser discutida, nomeadamente considerando que esta se serve das mais diversas formas de expressão material e de veiculação, as quais se apresentam cada vez mais difusas. Na contemporaneidade, as linhas de delimitação entre a arquitectura e a imagem, o espaço territorial e o ciberespaço, tendem a apagar-se, concorrendo para um efeito tanto de "perturbação de categorias», quanto de esteticização generalizada (Mons, 2002). Assim sendo, podemo-nos interrogar: de que modo a publicidade agiliza transformações na cultura contemporânea, quer ao nível das representações, quer ao nível das percepções dos fenómenos? De que modo a publicidade nos serve para reflectir sobre essas mesmas transformações?

Não respondendo certamente a todas as questões enumeradas, o actual número da revista constitui um importante contributo para a área de estudos da Publicidade em Portugal, extrapolando eventualmente os interesses académico-científicos dos seus estudiosos e investigadores. O carácter inevitavelmente interdisciplinar das abordagens, metodologias e perspectivas de análise reflexiva da Publicidade, tal como neste número se dá conta, convida a um salutar encontro entre diferentes áreas de estudos, bem como a um desejável diálogo entre o mundo profissional e académico. $\mathrm{Na}$ perseguição de um tal objectivo insistiu desde logo o Grupo de Trabalho de Publicidade da SOPCOM (Sociedade Portuguesa de Ciências da Comunicação), ao qual se deve o impulso e a motivação que conduziram à produção deste número temático. De modo especial, deixo aqui os meus agradecimentos ao Professor Francisco Costa Pereira, Presidente do referido grupo, por todo o rigor, empenho e colaboração no acompanhamento das etapas várias que resultaram na presente publicação.

\section{Referências bibliográficas}

Lipovetsky, G. e Serroy, J. (2007) L'Écran global, Paris: Seuil.

Mons, A. (2006) Paysage d'images. Essai sur les formes diffuses du contemporain, Paris: L'Harmattan.

Quessada, D. (2002) L'Esclavemaître, Paris: Seuil. 